\title{
The Brazilian version of the Home Falls and Accidents Screening Tool (HOME FAST): translation, cross-cultural adaptation, validation and reliability
}

Jarbas Melo Filhol $\mathbb{1 D}$

Silvia Valderramas ${ }^{2}$ (D)

Audrin Said Vojiciechowski ${ }^{3}$ ID

lynette Mackenzie 4 (ID)

Anna Raquel Silveira Gomes ${ }^{5} \mathbb{D}$

Abstract

Objective: to translate and cross-culturally adapt the Home Falls and Accidents Screening Tool - HOME FAST into Brazilian Portuguese and to evaluate its construct validity and intra-and inter-rater reliability. Method: a cross-sectional study was carried out that included older people aged 60 years or older. Translation and cross-cultural adaptation were carried out in the following stages: 1. Translation, 2. Synthesis, 3. Back translation, 4. Expert panel (review and pre-final version), 5. Pre-testing, 6. Analysis by the expert panel and the final version of the instrument. The Berg Balance Scale - BBS was used to test construct validity (Spearman correlation coefficient). Additionally, intra-and inter-rater reliability analysis was conducted using the Intraclass Correlation Coefficient (ICC) and the Bland-Altman plot. Results were considered significant at $p<0.05$. Results: the HOME FAST-Brazil was applied to 53 older people with a mean age of $71(5)$ years; $79 \%$ (42) of whom were female and 21\% (11) of whom were male. The translation and cross-cultural adaptation process resulted in similar versions among translations. The correlation of the total score of HOME FAST-Brazil with the BBS was $\varrho=-0.241, p=0.041$. The reliability rate was ICC $=0.99$ and 0.92 (intra-and inter-rater, respectively). Conclusion: The HOME FAST-Brazil, translated and cross-culturally adapted to Brazilian Portuguese, was shown to have construct validity and excellent intra-and inter-rater reliability.

\footnotetext{
Instituto Federal do Paraná, Curso Técnico e Tecnólogo em Massoterapia. Curitiba, PR, Brasil.

2 Universidade Federal do Paraná, Programa de Pós-Graduação em Medicina Interna e Departamento de Prevenção e Reabilitação em Fisioterapia. Curitiba, PR, Brasil.

3 Universidade Federal do Paraná, Programa de Pós-Graduação em Educação Física e Hospital Cardiológico Constantini. Curitiba, PR, Brasil.

4 The University of Sydney, Faculty of Health Sciences, Discipline of Occupational Therapy. Lidcombe, NSW, Austrália.

5 Universidade Federal do Paraná, Programa de Pós-Graduação em Educação Física e Departamento de Prevenção e Reabilitação em Fisioterapia. Curitiba, PR, Brasil.
}

Funding: the Coordenacão de Aperfeiçoamento de Pessoal de Nível Superior - Brasil (CAPES), Finance Code 001 (PhD and Masters Fellowships); Programa de Apoio à Pós-Graduação e à Pesquisa Científica e Tecnológica em Tecnologia Assistiva no Brasil (PGPTA), N 59/2014; Conselho Nacional de Desenvolvimento Científico e Tecnológico (CNPq), Process number 306179/2016-4 (a productivity fellowship).

\section{Keywords: Accidental Falls. Health of the Elderly. Environmental Hazards. Housing. Validation Study. Reproducibility of Results.}




\section{INTRODUCTION}

Falls are considered a global public health issue, and significantly contribute to the increase in the rate of injuries, hospitalizations, and deaths among the older population ${ }^{1}$. Approximately $30 \%$ of older people fall at least once a year, and the home environment is the main location of falls ${ }^{1-4}$.

Factors related to falls can be intrinsic, such as dysfunctions in the systems involved in postural control (the sensory, musculoskeletal and central nervous systems). Their risk factors can also be extrinsic, and include environmental risks, such as loose mats, slippery surfaces, poor lighting, inadequate clothes and shoes, poorly kept public roads, among others'.

Review studies have shown the most prevalent environmental factors related to falls are irregular, wet, or slippery floor surfaces, loose objects and/or mats, uneven ground and issues with stairs ${ }^{5,6}$. Rossetin et al. ${ }^{7}$ pointed out that environmental hazards, such as stairs, mats and loose tiles, were more present in the homes of older people who fell than in the homes of those who did not. Additionally, an association between falls and environmental factors was found among older people, such as stairs; uneven floors; pets, lack of anti-slip mats in the bedroom and kitchen; and objects on the bedroom floor ${ }^{8}$.

The number of household hazards and injuries related to falls may be reduced when there is an evaluation and interventions to improve the environment and guide residents on the risks present to older people within their own homes ${ }^{1,9-12}$. This usually requires an in-person visit to the home. Additionally, the risk of falls among older people may also be reduced by regular multimodal exercises (balance, strength, flexibility), physical therapy, and the review of psychotropic drugg ${ }^{1,12,13}$.

Some standardized instruments with demonstrated clinometric properties have already been developed for measuring home hazards related to risk of falls among older people living in the community. The Home Falls and Accidents Screening Tool (HOME FAST) was one such instrument, and demonstrated strong potential for evaluating home hazards, with a cut-off point for the risk of falls ${ }^{14}$. Nonetheless, most of the instrument available take a long time to apply, do not relate to the functionality of older adults in performing home activities, have no cut-off point for risk of falls and/ or are not translated and validated into Brazilian Portuguese. Therefore, standardized instruments designed to assess risk of falls within residential environments in Brazilian Portuguese are lacking, which in turn, means that preventative strategies for falls may not be based on accurate data.

The HOME FAST is composed of items assessing safety, function and mobility factors in the homes of older adults, and was developed in order to address the main risk factors for falls within the home ${ }^{15}$. This instrument has good potential for assessing the domestic risks linked to falls, since it has satisfactory evidence on psychometric and clinical properties and requires minimal training. Moreover, this material is designed specifically for older people at risk of falling, comprises fewer items and is openly available ${ }^{14,16}$.

Considering the need for assessment of the risk of falls in the home environments of older Brazilians, and the lack of instruments in Brazilian Portuguese, the objective of the present study was to translate and cross-culturally adapt the Home Falls and Accidents Screening Tool into Brazilian Portuguese and assess both its construct validity and intra-and inter-rater reliability.

\section{METHOD}

This is a cross-sectional study of the translation, cross-cultural adaptation and assessment of psychometric properties, and was approved by the Ethics Committee of Faculdade Dom Bosco, Paraná (register 1.203.602), Curitiba City Hall, and the State Department of Health (register 1.254.580), all in Brazil, according to National Health Council Resolution 466/2012. Prior consent from the creator of the HOME FAST was obtained from Dr. Lynette Mackenzie, at the University of Sydney, Australia.

The inclusion criteria were: older people of both sexes, aged 60 years or older, who were initially assessed in Health Care Centers in the city of Curitiba (Paraná) and who agreed to home visits from the researchers on two occasions. Data collection 
occurred between June 2016 and February 2018. Individuals with neurological or musculoskeletal problems which could limit their performance in the procedures of the study were excluded.

The following data were evaluated in order to characterize the sample: sex; age; height and weight, to calculate Body Mass Index (BMI), measured by scales and stadiometers; residence (single-story house; multi-story house or apartment); whether the older adult lives alone or, if not, who they share their home with (spouse; children; others); schooling (illiterate; $1-4$ years; $5-8$ years; $>8$ years); and falls in the last year, through the question: have you fallen in the last 12 months? Participants were also asked about the place where the fall occurred.

The HOME FAST instrument has the goal of assessing the risk of falls within the homes of older people. A rater, together with the older person and/or caregiver, visited the house and checked the rooms, in order to assess the presence of environmental attributes that could trigger a fall event, as well as the attitudes of the older person in the face of these risks. The use of the HOME FAST requires an observational assessment to be made of how the older person manages each item assessed in their home ${ }^{15}$.

In total, the HOME FAST contains 25 items related to key safety factors, functional tasks and the individual's mobility in domestic environments. The items refer to the floors, furniture, lighting, bathroom, storage, stairs, and function/mobility. Each item contains a definition to guide the evaluator, and questions must be answered with yes, no, or, in some cases, not applicable. The result is given by the sum of the answers marked only as no. The closer the final sum is to 25 points, the higher the risk of falls within the domestic environment ${ }^{15}$.

The questions can also be grouped under seven domains: floors, furniture, lighting, bathroom, storage, stairways/steps and mobility ${ }^{15}$. Additionally, if a score of 8 points or more is achieved, the home environment is considered as containing a high risk of falls ${ }^{17}$.

Translation and cross-cultural adaptation of the HOME FAST were performed according to Beaton et al. ${ }^{18}$, following the stages: 1 . Translation; 2 . Synthesis; 3. Back translation; 4. Expert panel (review and pre- final version); 5. Pre-testing; 6. Analysis by the expert panel and the final version of the instrument.

1. Two bilingual translators (Portuguese/ English), native to Brazil, fluent in both languages, independently performed the translation of the instrument into Brazilian Portuguese. One of the translators is a health professional, with prior knowledge of the objectives of the study, and the other is an English language teacher. This stage resulted in two initial translations in Portuguese: version 1 (T1) and version 2 (T2). It is worth noting that the instrument was translated in its entirety, including the definitions for each question, in order to guide the evaluators.

2. Both translations were compared and analyzed in a meeting with the translators and the researchers involved in the study. Differences from the two initial translations were reduced, and the cultural context of the Brazilian population and the original concepts of the instrument were preserved. This resulted in a consensual version of the questionnaire in Portuguese, hereby titled T12.

3. In addition, two bilingual English language teachers, who had English as their native language, independently performed the back-translation, that is, from the Brazilian Portuguese version into English, and verified the differences in relation to the original material. During this stage, the translators received no additional information about the study or the instrument to be translated.

4. Versions T12, the back translation and the original were submitted to an expert panel, comprised of all four bilingual translators, three health professionals (one from Physical Education, one from Physical Therapy and a third from Medicine) and the researchers of the study. The experts assessed the semantics, idiomatic expressions, cultural and conceptual equivalences, and identified and discussed any discrepancies. When a consensus was reached, a new version, named the HOME FAST-Brazil, was established, along with its respective version in English. 
5. In the pre-testing stage, rater 1 applied the HOME FAST-Brazil to participants in their home environment. At the end of each visit and after the assessment of the home environment, rater 1 read the instrument in its entirety to the participants in order to clarify possible doubts or misunderstandings regarding the items. The goal of this stage was to identify difficulties in the use of the HOME FASTBrazil and to provide solutions to ensure improved comprehension of the questionnaire. In the case of a misunderstanding regarding one or more items of the instrument, and of over $20 \%$ of the assessed sample, the parts were reviewed by the expert panel.

6. Finally, analysis was performed by the panel in order to discuss the results of pre-testing and obtain the final version of the HOME FAST-Brazil.

The construct validity of the HOME FAST-Brazil was tested to determine its association with another scale used in falls prevention work, namely the Berg Balance Scale (BBS) $)^{19,20,21}$. The BBS questionnaire aims to assess functional balance in different tasks, ranging from standing and walking to sitting and getting up from a chair, considering the effect of environment on the postural control required in daily life. From a total score of 56, the higher the value, the better the performance ${ }^{19}$.

Evaluation of the correlation between HOME FAST-Brazil and BBS was justified due to a lack of valid instruments in Brazilian Portuguese to assess home hazards related to falls. In addition, it was hypothesized that a higher risk of home falls (evaluated by HOME FAST) was related to worse postural balance (assessed by the BBS).

The assessment of reliability was performed according to Terwee et al. ${ }^{20}$ and Mokkink et al. ${ }^{21}$. Once the translation and cultural equivalence were established, the questionnaire was applied three times at the home of the participant. The first two assessments were carried out on the same day by two independent raters, rater 1 and rater 2 (inter-rater), at the same time, with each rater conducting their observation independently by checking the home environment as recommended in HOME FAST. The second assessment was performed 7 days after the first, by rater 1 only (intra-rater).

In 2016 the Municipal Health Secretary of Curitiba, Brazil, a city of 1,751,907 of inhabitants, of whom $11.3 \%$ are aged 60 or older, served 100,194 older adults across nine city districts. Participants from 16 Health Units in the city, selected by convenience from five districts, were personally invited. The sample size was estimated based on the recommendations of Beaton et al. ${ }^{18}$ for the process of translation and cross-cultural adaptation $(n=30$ 40 participants), and Terwee et al. ${ }^{20}$ and Mokkink et al. ${ }^{21}$ for validation and reliability $(\mathrm{n}=$ at least 50 participants). After a participant agreed to take part in the study they signed an informed consent form and a visit to their home for the application of the HOME FAST-Brazil by the researchers was scheduled.

The results are presented as descriptive statistics (mean \pm standard deviation, absolute and relative frequencies). In order to analyze the construct validity, the Spearman correlation coefficient was applied between the HOME FAST-Brazil and the BBS. Additionally, the domains of the HOME FAST-Brazil were related to the BBS questionnaire, considering: <0.1, trivial; between 0.1-0.29, small; $0.30-0.49$, moderate; $0.50-0.69$, high; $0.70-0.90$, very high; $>0.90$, almost perfect. Nevertheless, results were considered significant when $p<0.05$.

To test intra-and inter-rater reliability, the Intraclass Correlation Coefficient (ICC) was used for the sum of the items of the HOME FASTBrazil, with reliability ICC values $>0.70$ considered positive ${ }^{20,21}$ (poor to moderate reliability $<0.74$; good reliability $0.75-0.89$ and excellent reliability $>0.90$ ). In addition, we employed the Bland-Altman plot to evaluate the magnitude of differences among the two measurement procedures of the same variable ${ }^{20}$. All the values of the inter-and intra-rater differences were expected to be arranged in parallel around the zero horizontal axis and within the limits of agreement. 


\section{RESULTS}

A total of 53 older adults participated in the study, and 43 residences were assessed. In ten of these homes, the participants were married couples. Thus, for the analysis of construct validity of the instrument, all 53 participants were considered. As for the analysis of reliability, the data of 50 participants were used, as three of the older adults were assessed only once due to a shortage of raters in the week following the first assessment.
The general characteristics of the participants are presented in Table 1.

The process of translation and cross-cultural adaptation of the HOME FAST into Brazilian Portuguese produced similar versions, namely T1 and T2. Table 2 shows the small adjustments in the items of the instrument, which were made in order to create version T12. In item 6 , the word "sofá" was added to encompass situations in which the participant did not own the item of furniture "lounge chair".

Table 1. Characteristics of the participants (N=53). Curitiba, Paraná, 2016-2018.

\begin{tabular}{|c|c|c|}
\hline Characteristics & $\mathrm{n}(\%)$ & Mean(sd) \\
\hline \multicolumn{3}{|l|}{ Sex } \\
\hline Male & $11(20.8)$ & \\
\hline Female & $42(79.2)$ & \\
\hline Age & & $71( \pm 5)$ \\
\hline Body Mass Index & & $27( \pm 4)$ \\
\hline \multicolumn{3}{|l|}{ Fall } \\
\hline No & $39(73.6)$ & \\
\hline Yes & $14(26.4)$ & \\
\hline \multicolumn{3}{|l|}{ Place of falls* } \\
\hline Only at home (including throughout the property areas) & $5(9.6)$ & \\
\hline Only outside home & $2(3.8)$ & \\
\hline Inside and outside home & $6(11.5)$ & \\
\hline \multicolumn{3}{|l|}{ Residence } \\
\hline Single-story house & $31(58.5)$ & \\
\hline Apartment & $17(32.1)$ & \\
\hline Multi-story house & $5(9.4)$ & \\
\hline \multicolumn{3}{|l|}{ With whom do you live? } \\
\hline With spouse & $34(64.2)$ & \\
\hline Alone & $11(20.8)$ & \\
\hline With children & $6(11.3)$ & \\
\hline Other & $2(3.8)$ & \\
\hline \multicolumn{3}{|l|}{ Schooling } \\
\hline Illiterate & $0(0)$ & \\
\hline $1-4$ years & $13(24.5)$ & \\
\hline $5-8$ years & $9(17.0)$ & \\
\hline$>8$ years & $31(58.5)$ & \\
\hline
\end{tabular}

n: number of participants; sd: standard deviation; ${ }^{*}$ One participant did not report his history of falls. 
Table 2. Changes in the process of translation and cross-cultural adaptation of HOME FAST-Brazil. Curitiba, Paraná, 2016-2018.

\begin{tabular}{|c|c|c|c|c|}
\hline Item & Original version & $\mathrm{T} 1$ & $\mathrm{~T} 2$ & T12 \\
\hline 1 & $\begin{array}{l}\text { Are walkways free of } \\
\text { cords and other clutter? }\end{array}$ & $\begin{array}{l}\text { As passagens são livres de } \\
\text { cordas e outros objetos? }\end{array}$ & $\begin{array}{l}\text { As calçadas estão livres de } \\
\text { cordas e outros itens? }\end{array}$ & $\begin{array}{l}\text { As passagens são livres de } \\
\text { fios e outros objetos? }\end{array}$ \\
\hline 2 & $\begin{array}{l}\text { Are floor coverings in } \\
\text { good condition? }\end{array}$ & $\begin{array}{l}\text { O piso está em boas } \\
\text { condiçõos? }\end{array}$ & $\begin{array}{l}\text { Os revestimentos do piso } \\
\text { estão em boas condições? }\end{array}$ & $\begin{array}{l}\text { O piso está em boas } \\
\text { condições? }\end{array}$ \\
\hline 3 & $\begin{array}{l}\text { Are floor surfaces non } \\
\text { slip? }\end{array}$ & $\begin{array}{l}\text { Os pisos são } \\
\text { antiderrapantes? }\end{array}$ & $\begin{array}{l}\text { As superfícies dos pisos } \\
\text { são antiderrapantes? }\end{array}$ & $\begin{array}{l}\text { Os pisos são } \\
\text { antiderrapantes? }\end{array}$ \\
\hline 4 & $\begin{array}{l}\text { Are loose mats securely } \\
\text { fixed to the floor? }\end{array}$ & $\begin{array}{l}\text { Os tapetes estão bem } \\
\text { fixados no chão? }\end{array}$ & $\begin{array}{l}\text { Os tapetes avulsos estão } \\
\text { fixados firmemente ao } \\
\text { piso? }\end{array}$ & $\begin{array}{l}\text { Os tapetes estão bem } \\
\text { fixados no chão? }\end{array}$ \\
\hline 5 & $\begin{array}{l}\text { Can the person get in } \\
\text { and out of bed easily and } \\
\text { safely? }\end{array}$ & $\begin{array}{l}\text { A pessoa pode deitar- } \\
\text { se e levanta-se da } \\
\text { cama facilmente e com } \\
\text { segurança? }\end{array}$ & $\begin{array}{l}\text { A pessoa consegue entrar } \\
\text { e sair da cama com } \\
\text { facilidade e segurança? }\end{array}$ & $\begin{array}{l}\text { A pessoa pode deitar- } \\
\text { se e levantar-se da } \\
\text { cama facilmente e com } \\
\text { segurança? }\end{array}$ \\
\hline 6 & $\begin{array}{l}\text { Can the person get up } \\
\text { from their lounge chair } \\
\text { easily? }\end{array}$ & $\begin{array}{l}\text { A pessoa consegue } \\
\text { levantar-se de sua } \\
\text { poltrona facilmente? }\end{array}$ & $\begin{array}{l}\text { A pessoa consegue } \\
\text { levantar de sua poltrona } \\
\text { facilmente? }\end{array}$ & $\begin{array}{l}\text { A pessoa consegue } \\
\text { levantar de sua poltrona e/ } \\
\text { ou sofá facilmente? }\end{array}$ \\
\hline 7 & $\begin{array}{l}\text { Are all the lights bright } \\
\text { enough for the person to } \\
\text { see clearly? }\end{array}$ & $\begin{array}{l}\text { Todas a lâmpadas são } \\
\text { claras o suficiente para } \\
\text { que a pessoa enxergue } \\
\text { com facilidade? }\end{array}$ & $\begin{array}{l}\text { A iluminação de todas as } \\
\text { lâmpadas é suficiente para } \\
\text { que a pessoa enxergue } \\
\text { com clareza? }\end{array}$ & $\begin{array}{l}\text { A iluminação de todas as } \\
\text { lâmpadas é suficiente para } \\
\text { que a pessoa enxergue com } \\
\text { clareza? }\end{array}$ \\
\hline 8 & $\begin{array}{l}\text { Can the person switch a } \\
\text { light on easily from their } \\
\text { bed? }\end{array}$ & $\begin{array}{l}\text { A pessoa consegue ligar } \\
\text { facilmente a luz da cama? }\end{array}$ & $\begin{array}{l}\text { A pessoa consegue } \\
\text { facilmente acender a luz } \\
\text { quando está em sua cama? }\end{array}$ & $\begin{array}{l}\text { A pessoa consegue } \\
\text { facilmente acender a luz } \\
\text { quando está em sua cama? }\end{array}$ \\
\hline 9 & $\begin{array}{l}\text { Are the outside paths, } \\
\text { steps and entrances well } \\
\text { lit at night? }\end{array}$ & $\begin{array}{l}\text { As calçadas externas, } \\
\text { degraus e entradas são } \\
\text { bem iluminadas à noite? }\end{array}$ & $\begin{array}{l}\text { As calçadas, degraus e } \\
\text { entradas fora da casa são } \\
\text { bem iluminados à noite? }\end{array}$ & $\begin{array}{l}\text { As calçadas, degraus e } \\
\text { entradas externas são bem } \\
\text { iluminados à noite? }\end{array}$ \\
\hline 10 & $\begin{array}{l}\text { Is the person able to get } \\
\text { on and off the toilet easily } \\
\text { and safely? }\end{array}$ & $\begin{array}{l}\text { A pessoa consegue entrar } \\
\text { e sair do banheiro com } \\
\text { facilidade e segurança? }\end{array}$ & $\begin{array}{l}\text { A pessoa consegue } \\
\text { sentar e levantar do vaso } \\
\text { sanitário com facilidade e } \\
\text { segurança? }\end{array}$ & $\begin{array}{l}\text { A pessoa consegue } \\
\text { sentar e levantar do vaso } \\
\text { sanitário com facilidade e } \\
\text { segurança? }\end{array}$ \\
\hline 11 & $\begin{array}{l}\text { Is the person able to get in } \\
\text { and out of the bath easily } \\
\text { and safely? }\end{array}$ & $\begin{array}{l}\text { A pessoa consegue entrar e } \\
\text { sair da banheira facilmente } \\
\text { e de maneira segura? }\end{array}$ & $\begin{array}{l}\text { A pessoa é capaz de entrar } \\
\text { e sair da banheira com } \\
\text { facilidade e segurança? }\end{array}$ & $\begin{array}{l}\text { A pessoa consegue entrar e } \\
\text { sair da banheira facilmente } \\
\text { e de maneira segura? }\end{array}$ \\
\hline 12 & $\begin{array}{l}\text { Is the person able to walk } \\
\text { in and out of the shower } \\
\text { recess easily and safely? }\end{array}$ & $\begin{array}{l}\text { A pessoa consegue } \\
\text { entrar e sair do 'box' do } \\
\text { banheiro com facilidade e } \\
\text { segurança? }\end{array}$ & $\begin{array}{l}\text { A pessoa consegue } \\
\text { entrar e sair do box do } \\
\text { chuveiro com facilidade e } \\
\text { segurança? }\end{array}$ & $\begin{array}{l}\text { A pessoa consegue } \\
\text { entrar e sair do 'box' do } \\
\text { banheiro com facilidade e } \\
\text { segurança? }\end{array}$ \\
\hline 13 & $\begin{array}{l}\text { Is there an accessible/ } \\
\text { sturdy grab rail/s in the } \\
\text { shower or beside the bath? }\end{array}$ & $\begin{array}{l}\text { Existe }(\mathrm{m}) \text { alguma(s) } \\
\text { barra(s) de apoio no } \\
\text { chuveiro ou na banheira? }\end{array}$ & $\begin{array}{l}\text { Há barra(s) de suporte } \\
\text { firme(s) e ao alcance da } \\
\text { mão no chuveiro ou ao } \\
\text { lado da banheira? }\end{array}$ & $\begin{array}{l}\text { Existe }(\mathrm{m}) \text { alguma }(\mathrm{s}) \\
\text { barra }(\mathrm{s}) \text { de apoio no } \\
\text { chuveiro ou na banheira? }\end{array}$ \\
\hline 14 & $\begin{array}{l}\text { Are slip resistant mats / } \\
\text { strips used in the bath/ } \\
\text { bathroom/shower recess? }\end{array}$ & $\begin{array}{l}\text { Tapetes e/ou fitas } \\
\text { antiderrapantes são usadas } \\
\text { no banheiro/banheira/ } \\
\text { box? }\end{array}$ & $\begin{array}{l}\text { Há tapetes ou frisos } \\
\text { antiderrapantes na } \\
\text { banheira, no quarto de } \\
\text { banho ou no box do } \\
\text { chuveiro? }\end{array}$ & $\begin{array}{l}\text { Tapetes e/ou fitas } \\
\text { antiderrapantes são usadas } \\
\text { no banheiro e/ou banheira } \\
\text { e/ou box? }\end{array}$ \\
\hline 15 & $\begin{array}{l}\text { Is the toilet in close } \\
\text { proximity to the bedroom? }\end{array}$ & $\begin{array}{l}\text { O banheiro é próximo ao } \\
\text { quarto? }\end{array}$ & $\begin{array}{l}\text { O banheiro fica próximo } \\
\text { ao quarto? }\end{array}$ & $\begin{array}{l}\text { O banheiro fica próximo } \\
\text { ao quarto? }\end{array}$ \\
\hline
\end{tabular}


Continuation of Table 2

\begin{tabular}{|c|c|c|c|c|}
\hline Item & Original version & T1 & $\mathrm{T} 2$ & T12 \\
\hline 16 & $\begin{array}{l}\text { Can the person easily } \\
\text { reach items in the kitchen } \\
\text { that are used regularly } \\
\text { without climbing, bending } \\
\text { or upsetting his or her } \\
\text { balance? }\end{array}$ & $\begin{array}{l}\text { A pessoa consegue } \\
\text { pegar itens normalmente } \\
\text { utilizados na cozinha sem } \\
\text { a necessidade de subir em } \\
\text { algo, inclinar o corpo ou } \\
\text { sem perder o equilíbrio? }\end{array}$ & $\begin{array}{l}\text { A pessoa consegue } \\
\text { alcançar facilmente os } \\
\text { itens de cozinha usados } \\
\text { regularmente sem subir } \\
\text { em algo, curvar-se ou } \\
\text { prejudicar seu equilíbrio? }\end{array}$ & $\begin{array}{l}\text { A pessoa consegue } \\
\text { pegar itens normalmente } \\
\text { utilizados na cozinha sem } \\
\text { a necessidade de subir em } \\
\text { algo, inclinar o corpo ou } \\
\text { sem perder o equilíbrio? }\end{array}$ \\
\hline 17 & $\begin{array}{l}\text { Can the person carry } \\
\text { meals easily and safely } \\
\text { from the kitchen to the } \\
\text { dining area? }\end{array}$ & $\begin{array}{l}\text { A pessoa consegue levar } \\
\text { suas refeições da cozinha } \\
\text { para a sala de jantar } \\
\text { facilmente? }\end{array}$ & $\begin{array}{l}\text { A pessoa consegue } \\
\text { levar os alimentos com } \\
\text { facilidade e segurança } \\
\text { da cozinha até o local de } \\
\text { refeições? }\end{array}$ & $\begin{array}{l}\text { A pessoa consegue levar os } \\
\text { alimentos com facilidade e } \\
\text { segurança da cozinha até o } \\
\text { local de refeições? }\end{array}$ \\
\hline 18 & $\begin{array}{l}\text { Do the indoor steps/stairs } \\
\text { have an accessible/sturdy } \\
\text { grab rail extending along } \\
\text { the full length of the } \\
\text { steps/stairs? }\end{array}$ & $\begin{array}{l}\text { Escadas ou degraus } \\
\text { internos possuem } \\
\text { corrimão ou barras de } \\
\text { apoio por toda a sua } \\
\text { extensão? }\end{array}$ & $\begin{array}{l}\text { Há uma barra de apoio } \\
\text { firme e fácil de alcançar } \\
\text { ao longo de toda } \\
\text { a extensão de degraus ou } \\
\text { escadas existentes dentro } \\
\text { da casa? }\end{array}$ & $\begin{array}{l}\text { Escadas ou degraus } \\
\text { internos possuem } \\
\text { corrimão ou barras de } \\
\text { apoio por toda a sua } \\
\text { extensão? }\end{array}$ \\
\hline 19 & $\begin{array}{l}\text { Do the outdoor steps/ } \\
\text { stairs have an accessible/ } \\
\text { sturdy grab rail extending } \\
\text { along the full length of } \\
\text { the steps/stairs? }\end{array}$ & $\begin{array}{l}\text { Escadas ou degraus } \\
\text { externos possuem } \\
\text { corrimão ou barras de } \\
\text { apoio por toda a sua } \\
\text { extensão? }\end{array}$ & $\begin{array}{l}\text { Há uma barra de apoio } \\
\text { firme e fácil de alcançar } \\
\text { ao longo de toda } \\
\text { a extensão de degraus ou } \\
\text { escadas existentes fora da } \\
\text { casa? }\end{array}$ & $\begin{array}{l}\text { Escadas ou degraus } \\
\text { externos possuem } \\
\text { corrimão ou barras de } \\
\text { apoio por toda a sua } \\
\text { extensão? }\end{array}$ \\
\hline 20 & $\begin{array}{l}\text { Can the person easily and } \\
\text { safely go up and down } \\
\text { the steps/stairs inside or } \\
\text { outside the house? }\end{array}$ & $\begin{array}{l}\text { A pessoa consegue subir e } \\
\text { descer os degraus/escadas, } \\
\text { internas e/ou externas, } \\
\text { facilmente e de forma } \\
\text { segura? }\end{array}$ & $\begin{array}{l}\text { A pessoa consegue subir } \\
\text { e descer os degraus e } \\
\text { escadas dentro e fora } \\
\text { da casa com facilidade e } \\
\text { segurança? }\end{array}$ & $\begin{array}{l}\text { A pessoa consegue subir } \\
\text { e descer os degraus e/ } \\
\text { ou escadas dentro e fora } \\
\text { da casa com facilidade e } \\
\text { segurança? }\end{array}$ \\
\hline 21 & $\begin{array}{l}\text { Are the edges of the } \\
\text { steps/stairs (both inside } \\
\text { and outside the house) } \\
\text { easily identified? }\end{array}$ & $\begin{array}{l}\text { As bordas dos degraus/ } \\
\text { escada (tanto interno } \\
\text { como externo da casa) } \\
\text { facilmente identificáveis? }\end{array}$ & $\begin{array}{l}\text { As beiradas de degraus } \\
\text { ou escadas (dentro e fora } \\
\text { da casa) são identificadas } \\
\text { com facilidade? }\end{array}$ & $\begin{array}{l}\text { As bordas dos degraus e/ } \\
\text { ou escadas (dentro e fora } \\
\text { da casa) são visualizados } \\
\text { com facilidade? }\end{array}$ \\
\hline 22 & $\begin{array}{l}\text { Can the person use the } \\
\text { entrance door/s safely and } \\
\text { easily? }\end{array}$ & $\begin{array}{l}\text { A pessoa consegue utilizar } \\
\text { a(s) porta(s) de entrada } \\
\text { facilmente e de forma } \\
\text { segura? }\end{array}$ & $\begin{array}{l}\text { A pessoa consegue } \\
\text { usar a(s) porta }(\mathrm{s}) \text { de } \\
\text { entrada com segurança e } \\
\text { facilidade? }\end{array}$ & $\begin{array}{l}\text { A pessoa consegue utilizar } \\
\text { a(s) porta(s) de entrada } \\
\text { facilmente e de forma } \\
\text { segura? }\end{array}$ \\
\hline 23 & $\begin{array}{l}\text { Are paths around the } \\
\text { house in good repair, and } \\
\text { free of clutter? }\end{array}$ & $\begin{array}{l}\text { As calçadas ao redor } \\
\text { da casa estão em boas } \\
\text { condições e livres } \\
\text { desobstruídos? }\end{array}$ & $\begin{array}{l}\text { Os caminhos ao } \\
\text { redor da casa estão } \\
\text { em boas condições e } \\
\text { desimpedidos? }\end{array}$ & $\begin{array}{l}\text { Os caminhos ao redor } \\
\text { da casa estão em boas } \\
\text { condições e desimpedidos? }\end{array}$ \\
\hline 24 & $\begin{array}{l}\text { Is the person currently } \\
\text { wearing well-fitting } \\
\text { slippers or shoes? }\end{array}$ & $\begin{array}{l}\text { A pessoa consegue, } \\
\text { atualmente, calçar bem } \\
\text { pantufas ou calçados? }\end{array}$ & $\begin{array}{l}\text { Atualmente a pessoa usa } \\
\text { chinelos ou calçados bem } \\
\text { ajustados? }\end{array}$ & $\begin{array}{l}\text { Normalmente a pessoa } \\
\text { usa chinelo ou sapatos } \\
\text { apropriados? }\end{array}$ \\
\hline 25 & $\begin{array}{l}\text { If there are pets - can } \\
\text { the person care for them } \\
\text { without bending or being } \\
\text { at risk of falling over? }\end{array}$ & $\begin{array}{l}\text { Se há animais de } \\
\text { estimação, a pessoa } \\
\text { consegue cuidar deles sem } \\
\text { inclinar-se ou sem expor- } \\
\text { se ao risco de cair? }\end{array}$ & $\begin{array}{l}\text { Caso haja animais de } \\
\text { estimação, a pessoa } \\
\text { consegue cuidar deles sem } \\
\text { precisar se curvar ou sem } \\
\text { risco de queda? }\end{array}$ & $\begin{array}{l}\text { Se há animais de } \\
\text { estimação, a pessoa } \\
\text { consegue cuidar deles sem } \\
\text { inclinar-se ou sem expor- } \\
\text { se ao risco de cair? }\end{array}$ \\
\hline
\end{tabular}

T1: translation version 1; T2: translation version 2; T12: consensus version between T1 and T2. 
Moreover, the HOME FAST presents its definitions for each of the 25 items so that the rater fully understands the questions. Thus, some modifications were made to the Brazilian Portuguese version: in item 2 , the word "taco" was added to the floor conditions, since in the original version the only reference shown was for "lajota" and "carpetes". In item 3 the word translated "piso de vinil" was changed to "piso de Paviflex" and the word "laminado" was added for the types of nonslip resistant floors. In this way, the question became more explanatory, contemplating types of floors such as "pisos de Paviflex", "cerâmica" and "laminado"; the only suitable surfaces were non-slip floors.

The word "sofá" was incorporated to item 6 , in addition to "poltrona". Additionally, more information was given to define this item, initially translated as "o assento não é nem macio demais ou baixo demais", but was rewritten to "O assento não é baixo demais nem macio demais a ponto de afundar". The word "abajur" was added to item 8 , related to "luz de cabeceira ou iluminações noturnas".

Synonyms were also used to improve the ease of understanding of Brazilian readers, as in the case of the definition of item 10, in which the word "cadeira higiênica" was used in addition to the translation "cadeira de banho" as a complement.

In item 11 the words "borda" and/or "assento" were used as a translation of the English word "bath board". In item 20 the translation of the word "medical factors", which initially referred to "condições médicas", was later defined as "condições patológicas". In item 23, the word "irregular" was added to the sentence "sem calçadas irregulares e/ ou quebradas e/ou soltas" in order to complement the question.

Additionally, we to item 24 the sentence "Se a pessoa não usar calçados dentro de casa" to item 24 , instead of only "Se a pessoa não usar calçados". Finally, in item 25 the sentence "os animais não exigirem muito exercício" was replaced by "os animais não requerem muito trabalho".
Regarding the total score of the HOME FASTBrazil instrument, the mean of the sample was $5.45( \pm 2.09)$ hazards. When considering the risk of falls with a score $\geq 8$ in the instrument, the participants did not present a high risk of home falls. However, regarding the frequency analysis, eight $(15 \%)$ of the participants presented a high risk of home falls (score $\geq 8$ ).

The main risks found in the households of participants according to the 25 items in the HOME FAST-Brazil were: loose carpets $(92 \%)$, lack of support bars in the bathroom (81\%), lack of non-slip floors in the kitchen, bathroom and laundry $(79 \%)$ and no handrails or grab bars on the steps or stairs outside the house (60\%) (Figure 1).

When analyzing the frequency of risk of falls according to the distribution of the HOME FASTBrazil items in their domains, the following results were observed: $96 \%$ risk for the floors domain; $87 \%$ for the bathroom domain; $85 \%$ for the stairways/ steps domain; $40 \%$ for the lighting domain; $17 \%$ for the furniture domain; $9 \%$ for the mobility domain and $2 \%$ for the storage domain.

For construct validity evaluation, the correlation of the total score between the HOME FAST-Brazil and BBS was $\varrho=-0.241, p=0.041$. Moreover, when the domain scores of the HOME FAST-Brazil were related with the BBS questionnaire, the significant results were: furniture with BBS $\varrho=-0.434, p=0.001$ and bathroom with BBS $\varrho=-0.240, p=0.042$.

When analyzing the intra-and inter-rater reliability for the sum of the items of the HOME FASTBrazil, the intra-rater ICC was $0.99,95 \% \mathrm{CI}=0.98$ $0.99, p=0.000$, and the inter-rater ICC was 0.92 , $95 \% \mathrm{CI}=0.86-0.95, p=0.000$, both of which are considered excellent intra-and inter-rater reliability.

It was observed, through the Bland-Altman plot, that the majority of the differences in the intra and inter-rater values are arranged within the limits of agreement, as shown in Figure 2. 


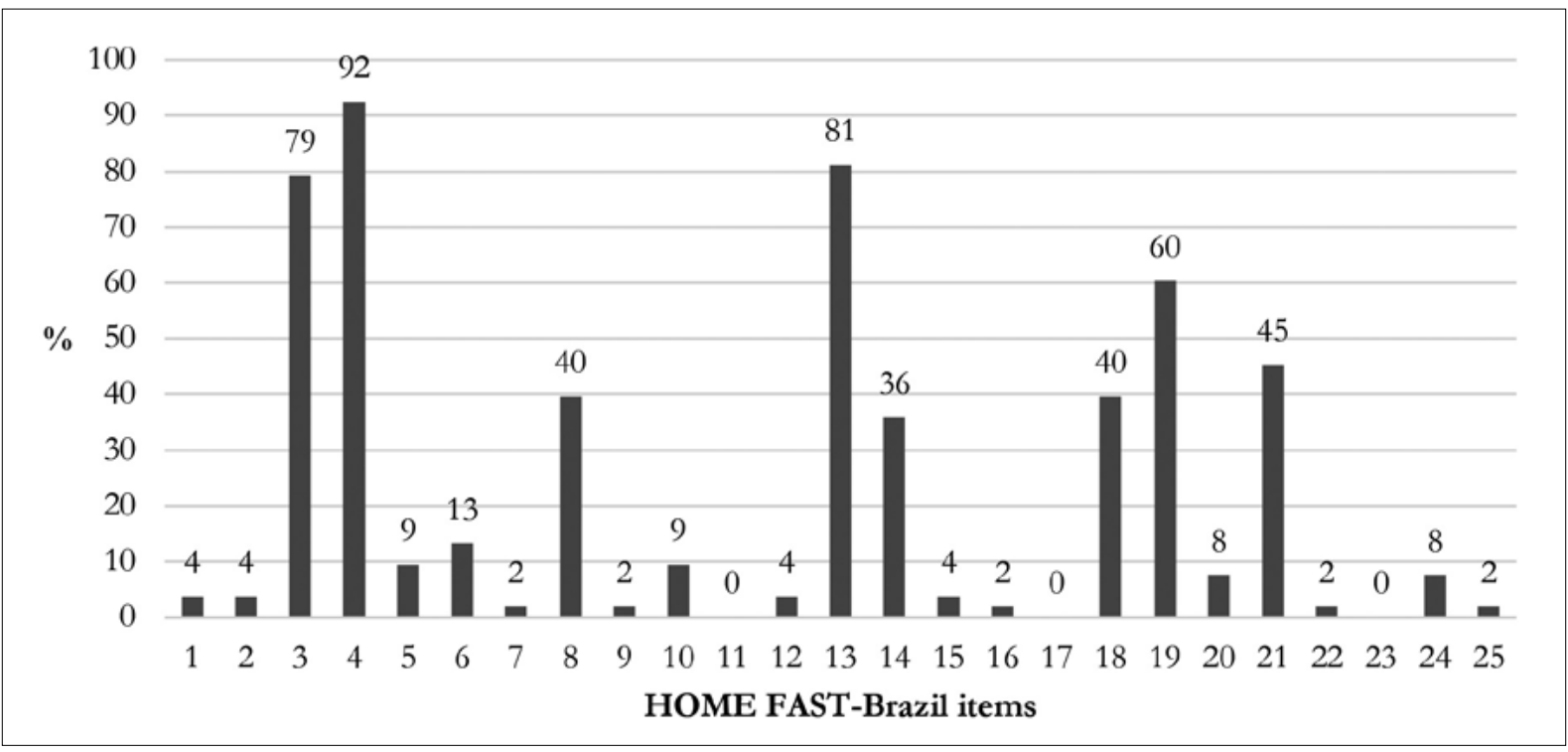

Figure 1. Percentage (\%) of risks of home falls from the 25 items of the HOME FAST-Brazil. Curitiba, Paraná, 2016-2018.

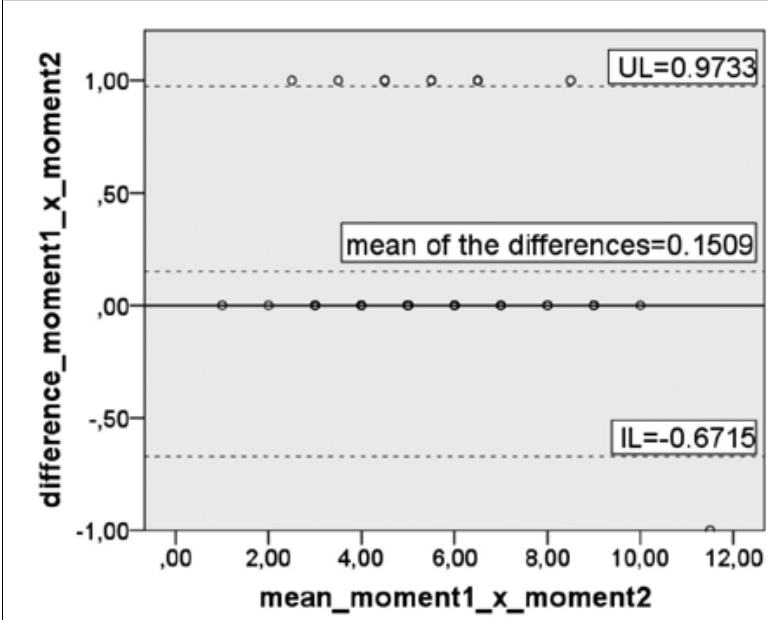

A. Intra-rater difference HOME FAST-Brazil items.

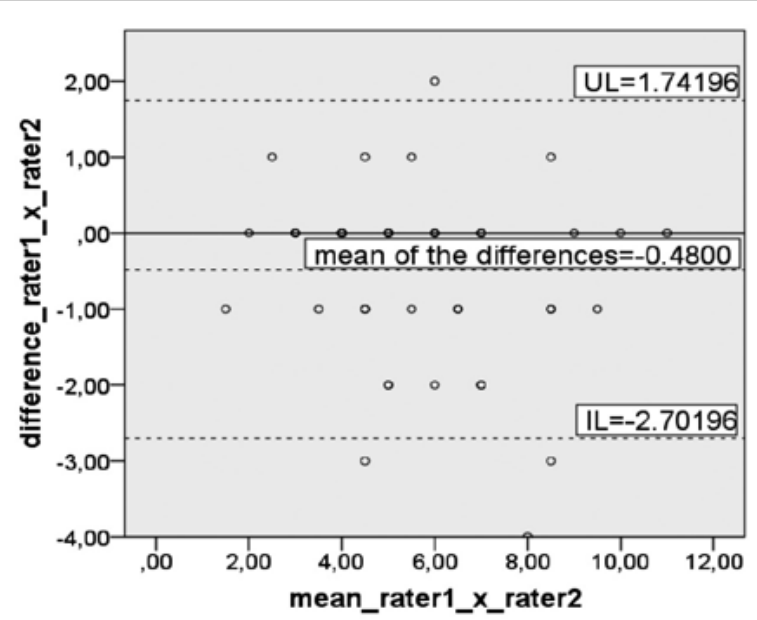

B. Inter-rater difference HOME FAST-Brazil items.

UL: upper limit; IL: inferior limit.

Figure 2. Bland-Altman plots of the differences between measures 1 and 2 of rater 1 (intra-rater) (A) and between measures of rater 1 and 2 (inter-rater) (B) for the sum of the items of the HOME FAST-Brazil. Curitiba, Paraná, 2016-2018. 


\section{DISCUSSION}

The HOME FAST-Brazil instrument was translated and cross-culturally adapted into Brazilian Portuguese, presenting construct validity and excellent reliability for the evaluation of the risk of falls in the home environment among Brazilian older adults.

Falls among older people display multifactorial risks, and concerns about the risks of home falls should therefore be incorporated into any control and prevention strategies. The frequency of falls found in the present study $(26.4 \%)$ corroborates Brazilian and international findings ${ }^{1-4}$. The HOME FAST-Brazil showed that the risk of home falls of Brazilian participants (5.4 points) was lower than the risks observed in the homes of older people in Scotland (8.6 points) ${ }^{22}$. It is worth noting that the risk of falls may vary among different populations, since the sample in the present study was composed of older people living in urban areas in the city of Curitiba (Paraná), while the participants in the study under discussion were older people living in urban and rural areas in Scotland.

Byles et al. ${ }^{17}$ found that $27 \%$ of a sample of 260 older people in Sydney (Australia) were at a high risk of falls (HOME FAST $\geq 8$ ), and identified the main risk factors as: absence of non-slip flooring; absence of non-slip mats; absence of support bars in the shower; and difficulties in identifying the edges of stairs. In the present study, the frequency of the risk of falls was lower (15\%), however, the main risks appear to be similar in both studies and include easy to fix problems, such as non-slip mats, non-slip flooring and support bars in homes.

Changes in the environment may contribute to the reduction of the risk of falls ${ }^{1,9-12}$. In a preventive health study, Mackenzie et al. ${ }^{16}$ observed that the average number of home hazards significantly decreased after a 3-year follow-up period in 727 older people from urban and rural areas in Australia. In addition, the chance of these older people falling increased from 1 to $2 \%$ when the HOME FAST score increased. Thus, the HOME FAST can also be used to identify older people at risk of falls in combination with the measurement of other risk factors for falls.

The process of the translation and cross-cultural adaptation of the HOME FAST-Brazil into Brazilian Portuguese was successful, since the instrument contemplates the main risks of residential falls for older people and is easy to use for health professionals. In addition, it was clear when observing the items evaluated and how the older participants related to what was being evaluated, that the final version in Portuguese was effective.

To facilitate the understanding of the instrument regarding words, terms and expressions, each question has a definition, including examples, which help to reduce misunderstanding caused by regional differences and even schooling. In the definition of question 3, the terms "pisos de paviflex e/ou laminado e/ou cerâmica" " "paviflex and/or laminate and/or ceramic floors") are related to slippery floors. For the term "condições patológicas" ("pathological conditions"), in the definition of question 20, examples are given, such as "sindrome do pé caído, perda de sensacão nos pés, distúrbios nos controles de movimentos, etc" ("foot drop syndrome, loss of sensation in the feet, disorders in movement controls, etc."). Furthermore, in the definition of question 25 , for the statement "Os animais não requerem muito trabalho" " "the animals do not require a lot of work") in the translated questionnaire, the following definition is included "animais de estimação = qualquer animal pelo qual a pessoa seja responsável. Para pontuar como "sim", a pessoa não precisa alimentar animais de estimação quando eles estão pulando ou movimentando-se próximo aos pés, a pessoa não precisa se curvar em direção ao chão para encher novamente tigelas e/ou pratos ou limpar os animais. Os animais não requerem muito trabalbo" ""pets = any animal for which the individual is responsible. To score "yes", the individual does not need to feed pets when they are jumping or moving close to their feet, one does not need to bend towards the floor to refill bowls and/or plates or clean the animals. The animals do not require much work.") Thus, the definition refers to the fact that the older person does not need to feed, clean or take their pet for a walk, exposing themselves to the risk of falling. 
In assessing the construct validity of the instrument, a small and significant correlation was found with the BBS questionnaire, which, although it also assesses the risk of falls, was designed to measure postural balance. Despite this, this scale was chosen to test construct validity as in Brazilian Portuguese literature there are no other valid and reliable instruments to assess the risk of home falls among older people. Furthermore, the BBS aims to assess the functional performance of an older person involving balance in different situations, therefore considering the effect of the environment on function ${ }^{19}$.

In contrast to the current study, Mackenzie et al. ${ }^{22}$, found poor to excellent inter-rater reliability (experienced rater and another rater) with a sample of older people in Scotland. In the Persian version of HOME FAST, however, it was observed that the intra-rater agreement was moderate to excellent and the inter-rater reliability was poor to excellent ${ }^{23}$. The authors justified this by stating that the presence of multiple conditions in different homes with different people can affect the reliability of an instrument. However, these differences can also be related to the tests used for reliability analysis, since this study used the ICC, whereas the other studies under discussion used the Kappa Index.

Even with psychometric evidence of the reliability and validity of a tool, it is critical that the instrument possesses clinical applicability ${ }^{14}$. Mackenzie ${ }^{24}$ evaluated health professionals working in different services in the UK, Canada and Australia with the objective of evaluating the clinical utility of the HOME FAST from the perspective of instrument users, and found. The findings of the study were that the HOME FAST can be used as a screening tool in a variety of international scenarios, both in clinical settings and in scientific research, by different health professionals, and that many barriers would be overcome by developing a support manual for the practical use of the instrument.

Some participants in this present study already had LED bulbs (Light Emitting Diode) in their homes, and so in the lighting item of the HOME FAST-Brazil can be expanded to include illumination by LED lamps, in addition to incandescent and fluorescent lighting. Also in relation to house lighting, some participants were not accustomed to turning on their bedside lamps at night when available, or even turning on the bedroom lights. Hence, the light in their room came from other sources such as street lights. Furthermore, some participants wore rubber flip-flops to take a bath in place of using non-slip mats in the bath or shower recess.

Given the importance of the home environment as a risk factor for falls in older people, the incorporation of tools to evaluate the home contributes to the identifying and guiding of modifications to the environment. In addition, identifying hazards that cause falls in the home can help improve the understanding of older people about the risk of falls and prevention strategies to be implemented.

The present study has some limitations, such as the use of only one instrument to test construct validity. However, this was justified due to the lack of valid and reliable instruments to assess the risk of home falls in older people in Brazilian Portuguese. Despite the quick application of the HOME FASTBrazil (15-20 minutes), the costs involved in health professionals visiting the homes of older persons (both financial and in terms of time) should be considered in its adoption by Brazilian health services. The homes used in this study were not randomized and the final data indicated an imbalance in the sex and schooling of participants.

\section{CONCLUSION}

The HOME FAST-Brazil was translated and cross-culturally adapted into Brazilian Portuguese and was found to have construct validity and excellent intra-and inter-rater reliability. Therefore, risk factors for home falls can be assessed using the HOME FAST-Brazil, and can contribute to the control and prevention of falls in older people by health services and strategies, with the aim of ensuring safer and more accessible homes to promote greater independence and autonomy for older people.

Link to access the HOME FAST-Brazil questionnaire: https://stopfallsathome.com.au/ resources/tip-sheets/\#health-professionals 


\section{ACKNOWLEDGEMENTS}

The authors are grateful for the participation of Natália Boneti Moreira, Paulo Cesar Barauce Bento and Vitor Last Pintarelli in the consensus meeting. The Centro de Assessoria de Publicação
Acadêmica - CAPA, Universidade Federal do Paraná - UFPR, for translating the manuscript into English. Secretaria Municipal de Saúde de Curitiba, Paraná.

Edited by: Ana Carolina Lima Cavaletti

\section{REFERENCES}

1. World Health Organization. Integrated care for older people: guidelines on community-level interventions to manage declines in intrinsic capacity. Geneva: WHO; 2017.

2. Vieira LS, Gomes AP, Bierhals IO, Farías-Antúnez S, Ribeiro CG, Miranda VIA, et al. Falls among older adults in the South of Brazil: prevalence and determinants. Rev Saúde Pública;2018;52:1-12.

3. Nascimento CF, Duarte YAO, Lebrão ML, Chiavegatto Filho ADP. Individual and contextual characteristics of indoor and outdoor falls in older residents of São Paulo, Brazil. Arch Gerontol Geriatr. 2017;68:119-25.

4. Carneiro JA, Ramos GCF, Barbosa ATF, Vieira EDS, Silva JSR, Caldeira AP. Falls among the noninstitutionalized elderly in northern Minas Gerais, Brazil: prevalence and associated factors. Rev Bras Geriatr Gerontol. 2016;19(4):613-25.

5. de Oliveira AS, Trevizan PF, Bestetti MLT, de Melo RC. Fatores ambientais e risco de quedas em idosos: revisão sistemática. Rev Bras Geriatr Gerontol. 2014;17(3):637-45.

6. Maia BC, Viana PS, Arantes PMM, Alencar MA. Consequências das quedas em idosos vivendo na comunidade. Rev Bras Geriatr Gerontol. 2011;14(2):381-93.

7. Rossetin LL, Rodrigues EV, Gallo LH, Macedo DS, Schieferdecker MEM, Pintarelli VL, et al. Indicadores de sarcopenia e sua relação com fatores intrínsecos e extrínsecos às quedas em idosas ativas. Rev Bras Geriatr Gerontol. 2016;19(3):399-414.

8. Pereira SG, Santos CB, Doring M, Portella MR. Prevalence of household falls in long-lived adults and association with extrinsic factors. Rev Latinoam Enferm. 2017;25:e2900 [7 p.].

9. Gillespie LD, Robertson MC, Gillespie WJ, Sherrington C, Gates S, Clemson LM, et al. Interventions for preventing falls in older people living in the community. Cochrane Database Syst Rev. 2012;9:1-4.

10. Clemson L, Mackenzie L, Ballinger C, Close JCT, Cumming SRG. Environmental interventions to prevent falls in community-dwelling older people: a meta-analysis of randomized trials. J Aging Health. 2008;20(8):954-71.

11. Keall MD, Pierse N, Howden-Chapman P, Cunningham C, Cunningham M, Guria J, et al. Home modifications to reduce injuries from falls in the Home Injury Prevention Intervention (HIPI) study: a cluster-randomised controlled trial. Lancet. 2015;385(9964):231-8.

12. Phelan EA, Mahoney JE, Voit JC, Stevens JA. Assessment and management of fall risk in primary care settings. Med Clin North Am. 2015;99(2):281-93.

13. Moncada LVV, Mire LG. Preventing falls in older persons. Am Fam Physician 2017;96(4):240-7.

14. Romli MH, Mackenzie L, Lovarini M, Tan MP, Clemson L. The Clinimetric Properties of instruments measuring home hazards for older people at risk of falling: a systematic review. Eval Health Prof. 2018;41(1):82-128.

15. Mackenzie L, Byles J, Higginbotham N. Designing the Home Falls and Accidents Screening Tool (HOME FAST): selecting the items. Br J Occup Ther. 2000;63(6):1-10.

16. Mackenzie L, Byles JE, D’Este C. Longitudinal study of the Home Falls and Accidents Screening Tool in identifying older people at increased risk of falls. Australas J Aging. 2009;28(2):64-9.

17. Byles JE, Mackenzie L, Redman S, Parkinson L, Leigh L, Curryer C. Supporting housing and neighbourhoods for healthy ageing: findings from the Housing and Independent Living Study (HAIL). Australas J Aging. 2014;33(1):29-35

18. Beaton DE, Bombardier C, Guillemin F, Ferraz MB. Guidelines for the process of cross-cultural adaptation of self-report measures. Spine. 2000;25(24):3186-91. 
19. Miyamoto ST, Lombardi Junior I, Berg KO, Ramos LR, Natour J. Brazilian version of the Berg balance scale. Brazilian version of the Berg balance scale. Braz J Med Biol Res. 2004;37(9):1411-21.

20. Terwee CB, Bot SDM, De Boer MR, van Der Windt DA, Knol DL, Dekker J, et al. Quality criteria were proposed for measurement properties of health status questionnaires. J Clin Epidemiol. 2007;60(1):34-42.

21. Mokkink LB, Prinsen CAC, Bouter LM, de Vet HCW, Terwee CB. The COnsensus-based Standards for the selection of health Measurement INstruments (COSMIN) and how to select an outcome measurement instrument. Braz J Phys Ther. 2016;20(2):105-13.
22. Mackenzie L, Byles J, Higginbotham N. Reliability of the Home Falls and Accidents Screening Tool (HOME FAST) for identifying older people at increased risk of falls. Disabil Rehabil. 2002;24(5):266-74.

23. Maghfouri B, Mehraban AH, Taghizade G, Aminian $G$, Jafari H. Internal Consistency of reliability assessment of the Persian version of the 'Home Falls and Accident Screening Tool. Iran Rehabil J. 2013;11(18):46-50.

24. Mackenzie L. Evaluation of the clinical utility of the Home Falls and Accidents Screening Tool (HOME FAST). Disabil Rehabil. 2016;39(15):1489-1501. 